Egyptian Poultry Science Journal

http://www.epsaegypt.com

ISSN: 1110-5623 (Print) - 2090-0570 (On line)

\title{
DIRECT AND CORRELATED RESPONSES TO SHORT-TERM INDEX SELECTION FOR SOME ECONOMIC TRAITS OF JAPANESE QUAIL.
}

\author{
Mahmoud, Bothaina Y. F. ${ }^{1}{ }^{*}$, Abou Khadiga, G. ${ }^{2}$ and Ensaf A. El-Full ${ }^{1}$ \\ ${ }^{1}$ Fac. of Agric., Fayoum Univ., Egypt; \\ ${ }^{2}$ Fac. of Desert and Environmental Agric., Fuka, Matrouh, Alex. Univ., Egypt.
}

ABSTRACT: A selection experiment was conducted at the Poultry Research Center, Faculty of Agriculture, Fayoum University using a total number of 4923 birds of three successive hatches as a base population producing 655 females (333 for the selected line and 322 for the random bred control line) through four successive generations. The main results are summarized as follows:

1. There were significant differences due to generation effect for all BW's tested and all egg production-related traits studied, except at $\mathrm{BW}_{35}$ and $\mathrm{AGE}_{30}$. All BW's from 7 up to 35 days of age and all egg production-related traits -except $\mathrm{BW}_{1^{-}}$were significantly affected by line favouring the selected line compared to the control line.

2. In the control line, average phenotypic response per generation for ASM and $\mathrm{AGE}_{10}$ showed fluctuations over generations, estimated by regression of phenotypic means on generation numbers were significantly positive for ASM and $\mathrm{AGE}_{10}(2.17$ and 2.18 days). Significant positive changes for BW's at seven, 14, 21, 28 and 35 days of age being $0.79,4.55,6.84,7.58$ and $4.36 \mathrm{~g}$, respectively and $\mathrm{AGE}_{30}$ (1.96 days) however, negative significant changes were shown for $\mathrm{EM}_{10}, \mathrm{EM}_{30}$ and $\mathrm{EM}_{60}(-3.10$, 9.69 and $-15.96 \mathrm{~g}$ ) .

3. In the selected line, the average phenotypic response per generation of multi-trait selection index estimated by the regression of generation means on generation number in $\mathrm{ASM}, \mathrm{BW}_{\mathrm{SM}}, \mathrm{DN}_{10}$ and $\mathrm{AGE}_{10}$ were significantly negative being -0.86 day, $-3.30 \mathrm{~g},-0.25$ day and -0.99 day, respectively, but was positive for $\mathrm{BW} 14$ $(+1.97 \mathrm{~g})$.

4. Negative correlated significant changes were shown for all egg production-related studied traits $\left(\mathrm{EM}_{30}, \mathrm{EM}_{60}, \mathrm{DN}_{30}, \mathrm{DN}_{60}, \mathrm{AGE}_{30}\right.$ and $\mathrm{AGE}_{60}$ being -3.98,-8.55,-1.41,3.26,-2.06 and -4.07, respectively), except $\mathrm{EM}_{10}(1.75 \mathrm{~g}, \mathrm{P} \leq 0.01)$. The average genetic response per generation in $\mathrm{ASM}, \mathrm{BW}_{\mathrm{SM}}, \mathrm{DN}_{10}$ and $\mathrm{AGE}_{10}$ were -3.74 days, $-3.06 \mathrm{~g}$, 0.22 day and -4.12 days, respectively.

Key Words: Selection, short-term, index selection, economic traits and Japanese quail.

Corresponding author: bzidan07@yahoo.com \& bzidan2013@gmail.com 
5. Both the phenotypic and genetic responses per generation for multi-trait index were better for ASM, $\mathrm{DN}_{10}$ and $\mathrm{AGE}_{10}$.

6. Significant correlated positive phenotypic response changes in both of $\mathrm{EM}_{10}$ and $\mathrm{EM}_{30}$ being 4.96 and $6.36 \mathrm{~g}$, however there were negative significant responses for $\mathrm{BW}_{21}, \mathrm{DN}_{60}, \mathrm{AGE}_{30}$ and $\mathrm{AGE}_{60}(-3.97 \mathrm{~g},-2.16,-4.87$ and -4.92 days, respectively).

7. The realized response was more than the expected since, higher negative average genetic response per generation than expected genetic response for $\mathrm{ASM}, \mathrm{DN}_{10}$ and $\mathrm{AGE}_{10}$ were found. Positive expected genetic response for $\mathrm{BW}_{\mathrm{SM}}$ was obtained whereas negative average genetic response per generation for this trait was found.

8. Realized heritabilities $\left(\mathrm{Rh}^{2}\right)$ of the multi-trait selection index across three-generation ranged from medium to high being $0.55,0.36,0.17$ and 0.39 , respectively for ASM, $\mathrm{BW}_{\mathrm{SM}}, \mathrm{DN}_{10}$ and $\mathrm{AGE}_{10}$.

\section{INTRODUCTION}

The production potentialities of Japanese quail and its economic value depends on various traits like age at sexual maturity, body weight, number of eggs produced etc, some of which may be genetically antagonistic (e.g. egg number and egg weight). Effective selection on egg production in quails resulted in reduction of both egg weight and body size, however, an index of total performance involving many traits may not significantly harm body weight and egg size. The ultimate goal of a poultry breeder is to improve the overall genetic economic worth of the bird through multi-trait selection by considering maximum number of traits at a time (Sakunthala Devi and Ramesh Gupta, 2012). Actually, selection experiments provide the framework for the study of the inheritance of complex traits and allow the evaluation of theoretical predictions by testing observations against expectations since selection is one of the major methods to achieve this improve. The objectives of the selection experiments could differ depending on the time scale, short-term experiments, can be used to estimate genetic variances and covariances, test their consistency from different sources of information and estimate the magnitude of the initial rates of response to selection (Martinez et al., 2000). Genetic and environmental variation might vary among populations and environments then it should thus be estimated in different populations and environments (Khaldari et al., 2010). Gunes and Cerit (2001) and Camci et al. (2002) suggested that age at sexual maturity was fairly related to body weight and that quails with higher body weights at sexual maturity had higher egg production rate. Zelenka et al. (1984) reported that there are minimum ages, body weight and body composition values for attainment of sexual maturity in female birds. Thus, to select for good egg producers, it is important to establish the relationship between age and weight at first egg and egg production traits. This is supported by Oruwari and Brody (1988) who observed that chronological age alone is not a primary effecter of sexual maturity rather there is a complex relationship between age, body weight, body composition and sexual maturity.

Several investigations were made for growth, egg production and egg quality parameters in broiler and layer chicken (Bekele et al., 2010 and Amao et al., 2011). Such systematic extensive genetic studies on Japanese quail were not taken up (Narendra Nath et al., 2011) therefore, the present study was carried out to study the influence of multi-trait selection procedure including some egg production and body weight traits on the total performance of 
Japanese quail and response to selection and some genetic parameters of the population.

\section{Materials and Methods}

This study was conducted at the Poultry Research Center, Faculty of Agriculture, Fayoum University. A selection experiment using a total number of 4923 birds as a base population producing 655 females $(333$ for the selected line and 322 for the random bred control line) through four successive generations through October 2010 to December 2012. Data of the base population consists of three successive hatches, then data were collected for the first hatch only to maintain discrete generations for four successive generations after formation avoiding mating of close relatives to decrease the rate of inbreeding depression. The selected breeders were housed (two females were randomly assigned to each male) in breeding cages with the dimensions $20 \times 20 \times 25 \mathrm{~cm}^{3}$ with sloping floor for collecting the eggs. Eggs were collected daily in a pedigree system for each family depending on the shell color and patterns of each female when females were 11 to 14 weeks of age. The newly hatched chicks were wing banded by small size plastic bands, which were replaced by wing metal bands at 14 days of age. Chicks were brooded on floor until 10 days of age, at that time the young birds were transferred to an intermediate battery brooder. From hatch to five weeks of age, all quail fed ad libitum on a starter diet containing $24 \% \mathrm{CP}$ and $2900 \mathrm{~K} \mathrm{cal} / \mathrm{ME}$ and water. From six weeks to the end of the study, a breeder diet containing $20 \% \mathrm{CP}$, $2900 \mathrm{~K} \mathrm{cal} / \mathrm{ME} 2.25 \%$ calcium and $0.43 \%$ available phosphorous were supplied according to NRC (1994). Birds were in continuous light for the first two weeks of age and then reduced to 16 hours of light day thereafter. All birds were kept under the same managerial hygienic and environmental conditions.

\section{Statistical Analysis:}

Selection index was constructed to select a female line including age at first egg (ASM), body weight at sexual maturity $\left(\mathrm{BW}_{\mathrm{SM}}\right)$, days needed to produce the first ten eggs $\left(\mathrm{DN}_{10}\right)$ and age at the first 10 eggs $\left(\mathrm{AGE}_{10}\right)$. The index form was:

$$
\mathrm{I}=\mathrm{b}_{1} \mathrm{X}_{1}+\mathrm{b}_{2} \mathrm{X}_{2}+\mathrm{b}_{3} \mathrm{X}_{3}+\mathrm{b}_{4} \mathrm{X}_{4}
$$

where: $b_{1}, b_{2}, b_{3}$ and $b_{4}$ are derived optimum weighing factors for traits $\mathrm{X}_{1}, \mathrm{X}_{2}$, $\mathrm{X}_{3}$ and $\mathrm{X}_{4}$, respectively. The $\mathrm{b}_{\mathrm{i}}$ 's values were obtained by solving a simultaneous equations represented in matrix notation as $[\mathrm{P}][\mathrm{b}]=[\mathrm{G}][\mathrm{a}]$ where:

$[\mathrm{P}]=$ Phenotypic variance and covariance matrix

$[b]=$ a row vector of index coefficients to be computed

$[\mathrm{G}]=$ Genotypic variance and covariance matrix

$[\mathrm{a}]=\mathrm{a}$ row vector of relative economic values

$[\mathrm{b}]=\mathrm{P}^{-1} \mathrm{Ga}$

The relative economic values of the traits studied were calculated by estimating the change in the difference between cost and income per unit change in the trait as reported by Kolstad (1975) are shown in Table 1. These relative economic values for: 1 day earlier for ASM and BWSM, $-1 / 2$ day for the days needed to produce the first 10 eggs and $-1 / 2$ day for Age $_{10}$. Moreover, the relative economic values of the studied generation were calculated (Table 2).

\section{Selection Differential:}

ExSD : Expected selection differential $=\bar{X}_{\mathrm{s}}-\bar{X}_{0}$

where, $\bar{X}_{\mathrm{s}}$ and $\bar{X}_{0}$ are the means of selected group and the flock, respectively. $\mathrm{E}_{\mathrm{f}} \mathrm{SD}$ : Effective selection differential $=\sum \frac{\text { Xini }}{n i}-$ flock mean

where: $X_{i}$ is the observation on the $\mathrm{i}^{\text {th }}$ parent

$\mathrm{n}_{\mathrm{i}}$ is the number of progeny of $\mathrm{i}^{\text {th }}$ parent

Response to selection 
To evaluate genetic responses, the realized heritability and the slopes of cumulative genetic responses for all traits were calculated. To do this, line means in each generation were first calculated. The line- and generation-specific means for all traits were calculated using the following model (PROC MIXED, SAS, 2011):

$$
\mathrm{Y}_{\mathrm{ijk}}=\mu+\mathrm{L}_{\mathrm{i}}+\mathrm{G}_{\mathrm{j}}+\mathrm{L}_{\mathrm{i}} \times \mathrm{G}_{\mathrm{j}}+\mathrm{e}_{\mathrm{ijk}}
$$

where: $Y_{\mathrm{ijk}}=$ the observations for a trait; $\mu$ is the overall mean; $L_{i}=$ the fixed effect of $i^{\text {th }}$ line; $G_{j}=$ the fixed effect of $i^{\text {th }}$ generation; $\mathrm{L}_{\mathrm{i}} \times \mathrm{G}_{\mathrm{j}}=$ the interaction of $\mathrm{L}_{\mathrm{i}}$ and $\mathrm{G}_{\mathrm{j}}$; and $\mathrm{e}_{\mathrm{ijk}}=$ the random error term. Means were compared for line, generations as main effects and interactions by Duncan's new multiple range test (Duncan, 1955). A probability of $\mathrm{P}<0.05$ was required for significance.

\section{Average phenotypic and genetic responses per generation:}

Phenotypic and genetic responses were estimated for the studied traits: body weight (BW) at one, seven, 14, 21, 28 and 35 days of age, egg mass for the first ten eggs $\left(\mathrm{EM}_{10}\right)$, egg mass for the first 30 eggs $\left(\mathrm{EM}_{30}\right)$, egg mass for the first 60 eggs $\left(\mathrm{EM}_{60}\right)$, days needed to produce the first 30 eggs $\left(\mathrm{DN}_{30}\right)$, days needed to produce the first 60 eggs $\left(\mathrm{DN}_{60}\right)$, age at first 30 eggs $\left(\mathrm{AGE}_{30)}\right.$ and age at first 60 eggs $\left(\mathrm{AGE}_{60}\right)$.

The average genetic response per generation was estimated by regressing the deviation of generation means of the selected line from the means of random bred control line on generation number (Singh and Kumar, 1994). The average phenotypic response per generation is estimated by the regression of generation means on generation number according to Singh and Kumar (1994).

\section{Realized heritability:}

Realized heritability was obtained as the ratio of cumulative response (CR) to cumulative selection differential (CS) for the selected trait (Hill, 1972).

\section{RESULTS AND DISCUSSION}

Means of body weight at different ages as affected by generation and line are shown in Table 3 . There were significant $(\mathrm{P} \leq 0.000)$ differences due to generation effect for all BW's tested, except at 35 days of age. Higher BW's at one, seven and 28 days of age (9.12, 31.44 and $151.76 \mathrm{~g}$, respectively) were observed in $\mathrm{G}_{3}$ which had numerically higher $\mathrm{BW}_{35}$ than other generations. The $\mathrm{G}_{4}$ had the highest $\mathrm{BW}$ at 14 and 21 days of age (66.09 and 109.19g, respectively). All BW's from 7 up to 35 days of age were significantly affected by line $(\mathrm{P} \leq 0.000)$ favoring the selected line which had heavier BW's at 7, 14, 21, 28 and 35 days of age $(31.08,65.61,111.69$, 153.63 and 202.01g, respectively) compared to the control line, except for $\mathrm{BW}_{1}$. Similar significant generation effect on $\mathrm{BW}_{7}$ and $\mathrm{BW}_{14}$ in Japanese quail was reported by Naser and Abbas (2012) whereas generation insignificantly affected $\mathrm{BW}_{28}$.

Similarly, Okuda et al. (2014) found insignificant differences due to generation effect for body weight at 14 and 28 days of age (averaged $39 \mathrm{~g}, 96.66 \mathrm{~g}$, respectively) generally increased at the end of the first and second generation after selection, when compared to the base generation, however body weight for generation 1 was slightly higher than that of generation 2 .

Farrag (2011) reported highly significant differences for EN, ASM and EW between the selected line for high egg production until 90 days of age over three generation and the control lines in the third generation of selection. Narendra Nath et al. (2011) found significant higher body weights in selected population (8.87, 135.77, 76.53, 123.12, 160.05 and 181.62 $\mathrm{g}$, respectively) over the control population (9.08, $130.91,68.46,118.27,149.06$ and $169.93 \mathrm{~g}$, respectively) for body weights at hatch, 1, 2, 3, 4 and 5 weeks of age, respectively. Moreover, Tawefeuk (2001) reported significant improvement in body 
weights at hatch, two and four weeks of age through five generations of selection in the two lines. Conversely, line insignificantly affected $\mathrm{BW}_{7}, \mathrm{BW}_{21}$ and $\mathrm{BW}_{35}$ of Japanese quail over three selection generations, and $\mathrm{BW}_{1}, \mathrm{BW}_{14}$ and $\mathrm{BW}_{28}$ in the selected and control lines in the third generation $(\mathrm{P}<0.01)$.

Means of generation and line effects on related-egg production traits are presented in Table 4.There were fluctuations in all egg production-related traits studied across generations. All of these traits were significantly $(\mathrm{P} \leq 0.001)$ affected by generation, except $\mathrm{AGE}_{30}$. Higher estimates of $\mathrm{DN}_{30}, \mathrm{DN}_{60}$ and $\mathrm{AGE}_{60}$ were shown for $G_{1}$ than other generations. $\mathrm{G}_{2}$ had the heaviest $\mathrm{BW}_{\mathrm{SM}}, \mathrm{EM}_{10}, \mathrm{EM}_{30}$ and $\mathrm{EM}_{60}$, whereas $\mathrm{G}_{4}$ had the lowest $\mathrm{BW}_{\mathrm{SM}} \cdot \mathrm{G}_{3}$ had earlier ASM being 49.29 days and it had higher estimate of $\mathrm{DN}_{10}$ (13.22) but lower $\mathrm{EM}_{60}$ whereas the latest ASM and $\mathrm{AGE}_{10}$ however, lower $\mathrm{DN}_{10}, \mathrm{DN}_{30}$, $\mathrm{DN}_{60}$ and $\mathrm{AGE}_{60}$ were attained by $\mathrm{G}_{4}$ than other generations. Similarly, Okuda et al (2014) who estimated genetic parameters of egg production, reproductive traits in Japanese quail and response to selection for egg production after two generations of selection, Okenyi et al. (2013) who investigated the effect of selection for short-term (30 days) egg production trait in Japanese quail over three generations (EN, $\mathrm{BW}_{\mathrm{SM}}, \mathrm{EW}$ ) and Farrag (2011) who selected a line for high egg production until 90 days of age over three generation found significant generation effects on studied egg production traits (EN, ASM and EW) over three generations. Naser and Abbas (2012) found significant generation effect on body weight at maturation, egg mass in the first and second month, egg number in the first, second and the third month over two generation but generation insignificantly affected ASM and egg mass in the third month.

Line significantly $\quad(\mathrm{P} \leq 0.01)$ influenced all egg production-related traits studied, except $\mathrm{EM}_{30}$ and $\mathrm{EM}_{60}$ favoring selected line than control line (Table 4). The selected line had earlier ASM, DN 10 , $\mathrm{AGE}_{10}, \mathrm{DN}_{30}, \mathrm{DN}_{60}, \mathrm{AGE}_{30}$ and $\mathrm{AGE}_{60}$ by $7.45,2.35,9.66,5.75,7.55,12.49$ and 14.82 days, respectively, and heavier $\mathrm{BW}_{\mathrm{SM}}$ and $\mathrm{EM}_{10}$ by $6.80 \mathrm{~g}$ and $2.51 \mathrm{~g}$ than the control line. Alkan et al. (2013) found significant line effect on egg mass, egg number, egg weight and $\mathrm{BW}_{\mathrm{SM}}$ favoring the layer line for 120day egg production over 11 generations except $\mathrm{BW}_{\mathrm{SM}}$ than the control line but insignificant line effect on ASM. Farrag (2011) reported significant line effect on both ASM and egg number favoring the selected line for high egg production until 90 days of age over three generation but insignificantly affected egg weight. However, Reddish (2004) reported insignificant differences due to the line for $\mathrm{ASM}, \mathrm{BW}_{\mathrm{SM}}$ and first egg weight neither the third nor the sixth generation. Narendra Nath et al. (2011) reported that ASM was significantly lower (46.2 vs. 52.4 day) and egg weight was significantly higher at 16 week of age in the selected population $(13.78 \mathrm{~g}$ vs. $12.66 \mathrm{~g})$ than the control population. Similarly, egg production was significantly higher at 18 and 24 weeks in the selected population than the control population. Tawefeuk (2001) reported that there were a significant $(\mathrm{P}<0.001)$ decrease in the days needed to produce the first 10 eggs in the selected line for age at sexual maturity and days needed to produce the first 10 eggs from $100 \%$ to $54.00 \%$ (relative to control line in the same generation) in the base population to the $4^{\text {th }}$ generations. He found that ASM in egg production line selected through index included age at sexual maturity (days) and the period needed to produce the first 10 eggs significantly decreased $(\mathrm{P}<0.001)$ during the studied five generations from 59.02 to 44.73 , while in the control line this decrease was not found and the ASM ranged from 59.02 to 57.52 days, however, there were insignificant differences among lines or generations in absolute $\mathrm{BW}_{\mathrm{SM}}$. Bahie El-Deen (1994), Shalan (1998) and 
Ali et al. (2002) reported that the quail line selected for high egg production were better for egg production traits $\left(\mathrm{BW}_{\mathrm{SM}}\right.$, $\mathrm{EW}, \mathrm{ASM}$ and $\mathrm{EN}$ ) than other lines.

Generation $\mathrm{x}$ line interaction significantly $(\mathrm{P} \leq 0.000)$ affected $\mathrm{BW}$ at all studied ages (Table 5). The control line had the highest BW1 (9.77g) at $\mathrm{G}_{3}$, while the selected line had heavier BW's at seven, 14, 21,28 and 35 days of age being 32.96, 69.82, 115.19, 162.95 and 207.19 and $207.45 \mathrm{~g}$ at $\mathrm{G}_{3}, \mathrm{G}_{4}, \mathrm{G}_{1}, \mathrm{G}_{3}$ and $\mathrm{G}_{3}$, respectively. However, the control line had the lightest $\mathrm{BW}_{1}$ at $\mathrm{G}_{4}, \mathrm{BW}_{7}$ at $\mathrm{G} 1, \mathrm{BW}_{14}$, $\mathrm{BW}_{21}, \mathrm{BW}_{28}$ at $\mathrm{G}_{2}$ and $\mathrm{BW}_{35}$ at $\mathrm{G}_{3}$ of 8.14, 23.66, 49.30, 80.95, 113.92 and 170.62g), respectively. However, Farrag (2011) reported insignificant Generation $\mathrm{x}$ Line interaction effect on BW at all ages except body weight at hatch.

Effects of generation $x$ line interactions on some egg productionrelated traits were presented in Table 6 . There were significant effects for all egg production-related traits studied across generations, except $\mathrm{BW}_{\mathrm{SM}}$. The control line had later $\mathrm{ASM}, \mathrm{AGE}_{10}$ and $\mathrm{AGE}_{30}$ of 60.97, 73.19 and 98.17, at $\mathrm{G}_{4}$ respectively, and it had significant later $\mathrm{AGE}_{60}$ ranged from 130.08 for $G_{2}$ to 131.78 days for $G 3$ than other generation $x$ line groups. The control line had significant heavier $\mathrm{EM}_{10}$, $\mathrm{EM}_{30}$ and $\mathrm{EM}_{60}$ at $\mathrm{G}_{2}(122.47,380.15$ and $770.36 \mathrm{~g}$, respectively) however, the selected line at the fourth generation had insignificant different $\mathrm{EM}_{10}$ than the control line at $\mathrm{G}_{2}$ and had significant lower ASM, $\mathrm{DN}_{10}, \mathrm{AGE}_{10}, \mathrm{DN}_{30}, \mathrm{DN}_{60}, \mathrm{AGE}_{30}$, and $\mathrm{AGE}_{60}(46.54,11.06,57.58,31.91,64.39$, 78.81 and 111.11days, respectively). Higher $\mathrm{DN}_{10}, \mathrm{DN}_{30}$ and $\mathrm{DN}_{60}$ were shown for the control line at $\mathrm{G}_{3}(15.28,41.76$ and 79.59 days, respectively). Lower $\mathrm{EM}_{10}$, $\mathrm{EM}_{30}$ and $\mathrm{EM}_{60}$ were obtained for the control line at $\mathrm{G}_{4}$ being 109.05, 334.62 and $691.46 \mathrm{~g}$, respectively. Tawefeuk (2001) reported that the overall means of egg weight increased generally through generations, with significant $(\mathrm{P}<0.05)$ differences among generations within lines, and no significant differences were observed in egg production after five generations in the selected lines.

\section{Genetic parameters:}

Heritability, genetic and phenotypic correlations are shown in Table 7 . Heritability estimates for each of ASM, $\mathrm{BW}_{\mathrm{SM}}$ and $\mathrm{AGE}_{10}$ were moderate ranging between 0.21 and 0.27 , similar results were reported (Sezer et al., 2006 and Sezer, 2007) for ASM and Okenyi et al. (2013) for BWsm, whereas $\mathrm{DN}_{10}$ had the lowest estimate of 0.09 .

A high range of genetic correlations (0.47 to 0.95$)$ was shown among multiindex traits,

a wider range of positive phenotypic correlations ranged from 0.09 to 0.86 was found among multi-index traits, except $\mathrm{rp}$ between $\mathrm{DN}_{10}$ and $\mathrm{BW}_{\mathrm{SM}}$ being -0.03 .

\section{Response to selection:}

\section{Control line:}

Average phenotypic response per generation for $\mathrm{ASM}$ and $\mathrm{AGE}_{10}$ showed fluctuations over generations, regression of phenotypic means on generation numbers were significantly positive for ASM and $\mathrm{AGE}_{10}$ (2.17 and 2.18days) but were statistically insignificant for each of $\mathrm{BW}_{\mathrm{SM}}$ and $\mathrm{DN}_{10}$ (Table 8). Significant positive changes in the control line for BW's at seven, 14, 21, 28 and 35 days of age being $0.79, \quad 4.55, \quad 6.84, \quad 7.58$ and $4.36 \mathrm{~g}$, respectively and $\mathrm{AGE}_{30}$ (1.96days) however, negative significant changes were shown for $\mathrm{EM}_{10}, \mathrm{EM}_{30}$ and $\mathrm{EM}_{60}$ (-3.10, 9.69 and $-15.96 \mathrm{~g})$ as shown in Table 9. Significant systematic changes in performance of the control line had been reported in some of the earlier selection experiments (Nestor et al., 1982). Environmental variations as influenced by season of hatching could account for this variation among generations since quails were hatched twice a year in different seasons. However, the pattern of changes in 
means of control over generations fairly matched with those observed for the two selected lines indicating possibly these to be of the environmental origin (Brah et al., 2001).

\section{Selected line:}

The realized average phenotypic and genetic responses due to three generations of multi-trait selection index that was applied to select a female line (M) according to the age at first egg (ASM), body weight at sexual maturity $\left(\mathrm{BW}_{\mathrm{SM}}\right)$, days needed to produce the first ten eggs $\left(\mathrm{DN}_{10}\right)$ and age at 10 eggs $\left(\mathrm{AGE}_{10}\right)$ are presented in Table 8 . The average phenotypic response per generation estimated by the regression of generation means on generation number in ASM, $\mathrm{BW}_{\mathrm{SM}}, \mathrm{DN}_{10}$ and $\mathrm{AGE}_{10}$ were significant negative being -0.86 day, $-3.30 \mathrm{~g},-0.25$ day and -0.99day, respectively. There were insignificant average phenotypic response per generation for all BW's tested, except at 14 days of age $(1.97 \mathrm{~g}, \mathrm{P} \leq 0.000)$. Negative correlated significant changes were shown for all egg production- related studied traits $\left(\mathrm{EM}_{30}, \mathrm{EM}_{60}, \mathrm{DN}_{30}, \mathrm{DN}_{60}, \mathrm{AGE}_{30}\right.$ and $\mathrm{AGE}_{60}$ being -3.98,-8.55,-1.41,-3.26,-2.06 and -4.07 , respectively), except $\mathrm{EM}_{10}$ (1.75g, $\mathrm{P} \leq 0.01$ ).

The average genetic response per generation estimated by the regression of the deviation of generation means of selected flock from the means of random bred control on generation means in ASM, $\mathrm{BW}_{\mathrm{SM}}, \mathrm{DN}_{10}$ and $\mathrm{AGE}_{10}$ were -3.74days, $3.06 \mathrm{~g},-0.22$ day and -4.12 days, respectively (Table 8). It could be seen that the mean phenotypic and genetic response for multitrait index were negative. Both the responses were better for $\mathrm{ASM}, \mathrm{DN}_{10}$ and $\mathrm{AGE}_{10}$, the genetic response indicating maximal estimates than the phenotypic response at the age at which selection was carried out whereas the phenotypic response in $\mathrm{BW}_{\mathrm{SM}}$ was higher than the genetic response.
The expected genetic response to the selection was negative for $\mathrm{ASM}, \mathrm{DN}_{10}$ and $\mathrm{AGE}_{10}$ traits involved in the construction of index for base population while positive response was observed for $\mathrm{BW}_{\mathrm{SM}}($ Table 8). The present results reflect higher negative AGR per generation than expected genetic response for $\mathrm{ASM}, \mathrm{DN}_{10}$ and $\mathrm{AGE}_{10}$, while positive expected genetic response for $\mathrm{BW}_{\mathrm{SM}}$ whereas negative AGR per generation for this trait. Clearly, the realized genetic gains from this experiment did measure up to expectations. The realized response was more than the expected and it might be due to the construction of selection index for only females. Though we have selected the male parents it was only by indirect method of index selection and merit of the males was not taken in to the expected genetic response. The realized genetic response may also depend on number of chicks from the superior parents (Narendra Nath et al., 2011).Similarly, they reported lower expected genetic response for ASM than a realized genetic response of -0.02 vs -6.2 days however, larger expected genetic response than realized genetic response values for egg weight at 12 weeks of age (0.39 vs $0.03 \mathrm{~g}$ ) was observed. Raj Narayan et al. (2000) predicted an undesirable increase of 0.43 days in ASM, increase of 3.4eggs for EP18 in Japanese quail and noticed decrease of $-0.098 \mathrm{~g}$ in egg weight at 18 weeks of age in Japanese quail. The genetic progress achieved after four generations of selection on the main index was -11.08 for age at sexual maturity and 10.26 days for $\mathrm{DN}_{10}$. The expected genetic change per generation ranged between 0.85 to -1.73 days for ASM and from -0.62 to -1.22 days for $\mathrm{DN}_{10}$ (Tawefeuk, 2001). Punya Kumari (2007) predicted a genetic gain of - 0.0455 days for ASM and a genetic gain of 0.0731 eggs per one percent increase in Japanese quail for EP16.

As shown in Table 9, there were insignificant average phenotypic response per generation for all BW's tested, except at 
14 days of age $(1.97 \mathrm{~g}, \mathrm{P} \leq 0.000)$. Also, there were insignificant average genetic response per generation for all BW's tested, except at 21 days of age $(-3.97 \mathrm{~g}, \mathrm{P} \leq 0.01)$. Significant positive changes in all egg production-related traits $\left(\mathrm{EM}_{30}, \mathrm{EM}_{60}\right.$, $\mathrm{DN}_{30}, \mathrm{DN}_{60}, \mathrm{AGE}_{30}$ and $\mathrm{AGE}_{60}$ being $3.98 \mathrm{~g},-8.55 \mathrm{~g},-1.41,-3.26,-2.06$ and 4.07days, respectively), except $\mathrm{EM}_{10}$. Significant positive changes in both of $\mathrm{EM}_{10}$ and $\mathrm{EM}_{30}$ were found being 4.96 and $6.36 \mathrm{~g}$, however there were negative significant average genetic response per generation for $\mathrm{DN}_{60}, \mathrm{AGE}_{30}$ and $\mathrm{AGE}_{60}$ (2.16,-4.87 and -4.92 days, respectively).

\section{Selection Differentials:}

The expected $\left(\mathrm{E}_{\mathrm{x}} \mathrm{SD}\right)$ and effective $\left(E_{f} S D\right)$ selection differentials for the multitrait selection index traits are given in Table $8 . \mathrm{E}_{\mathrm{x}}$ SD's were higher than $\mathrm{E}_{\mathrm{f}}$ SD's. The values of selection intensity for the multi-trait selection index: $\mathrm{ASM}, \mathrm{BW}_{\mathrm{SM}}$, $\mathrm{DN}_{10}$ and $\mathrm{AGE}_{10}$ were 0.57, 0.12, 0.30 and 0.67 , respectively. The ratio of $\mathrm{E}_{\mathrm{f}} \mathrm{SD}$ to
$\mathrm{E}_{\mathrm{x}}$ SD's was lower than unity indicating that natural selection and/or chance did influence selection for ASM, $\mathrm{DN}_{10}, \mathrm{AGE}_{10}$ and $\mathrm{BW}_{\mathrm{SM}}$ with the ratios being $0.94,0.89$, 0.47 and 0.34 , respectively in a descending order (Table 8). Differences in natural selection differential, fertility and/or genetic environment interaction might be resulted in such irregularities in selection response (Aboul-Seoud, 2008) especially in such small numbers of generations as it was the case in the present study

Realized heritability was obtained as the ratio of cumulative response (CR) to cumulative selection differential (CS) for the selected trait (Hill, 1972). Heritabilities of the multi-trait selection index pooled on three-generation ranged from medium to high being $0.55,0.36,0.17$ and 0.39 , respectively for $\mathrm{ASM}, \mathrm{BW}_{\mathrm{SM}}, \mathrm{DN}_{10}$ and $\mathrm{AGE}_{10}$ with $\mathrm{ASM}$ had the highest $\mathrm{Rh}^{2}$ whereas the lowest estimate was shown for $\mathrm{DN}_{10}$ are presented in Table 8 . 
Table (1): Economic values of the multi-index traits studied.

\begin{tabular}{|c|c|c|c|}
\hline Item & Selected line & Item & Control line \\
\hline \multicolumn{4}{|l|}{ G1 (ASM and BW $\left.\mathrm{SM}_{\mathrm{SM}}\right)$} \\
\hline $\begin{array}{l}\text { Initial price of one } \\
\text { quail at 1-day }\end{array}$ & 100 Piasters $(\mathrm{P})$ & $\begin{array}{l}\text { Initial price of one } \\
\text { quail at } 1 \text {-day }\end{array}$ & 100 Piasters $(\mathrm{P})$ \\
\hline Feed for the first 42 & $650 * 300 \mathrm{P} / \mathrm{Kg}$ diet & Feed for the first 42 & $650 * 300 \mathrm{P} / \mathrm{Kg}$ diet \\
\hline days $(650 \mathrm{~g})$ & $=195 \mathrm{P}$ & days & $=195 \mathrm{P}$ \\
\hline Feed for( $48.83-42)$ & $6.83 * 25 \mathrm{~g} * 270 \mathrm{P} / \mathrm{Kg}$ & Feed for $(52.72-42)$ & $10.72 * 25 * 270 \mathrm{P} / \mathrm{Kg}$ \\
\hline $\begin{array}{l}\text { days } \times 25 \text { g day x } 270 \\
\mathrm{P} / \mathrm{kg} \text { diet }\end{array}$ & diet $=46 \mathrm{P}$ & $\begin{array}{l}\text { days } \mathrm{x} 25 \text { g day } \mathrm{x} \\
270 \mathrm{P} / \mathrm{kg} \text { diet }\end{array}$ & $\operatorname{diet}=70.336 \mathrm{P}$ \\
\hline $\begin{array}{l}\text { Other cost }(0.5 \text { total } \\
\text { feed cost })\end{array}$ & $=(46+195) * .05=120.5 \mathrm{P}$ & $\begin{array}{l}\text { Other cost }(0.5 \text { total } \\
\text { feed cost })\end{array}$ & $\begin{array}{l}=(70.33+195) * 0.5= \\
132.68 \mathrm{P}\end{array}$ \\
\hline Total & $461.5 \mathrm{P}$ & Total & $498 \mathrm{P}$ \\
\hline \multicolumn{4}{|c|}{ Income price of quail at sexual maturity $(600 \mathrm{P})$} \\
\hline Gain & $=600-461.5=138.5 \mathrm{P}$ & & $=600-498=102 \mathrm{P}$ \\
\hline \multicolumn{4}{|c|}{$\begin{array}{l}\text { Total gain for decreased age at sexual maturity for } 2 \mathrm{SD}=\text { income of (Selected } \mathrm{S}-\text { Control } \mathrm{C} \text { ) } \\
=138.5-102=36.5 \mathrm{P}\end{array}$} \\
\hline \multicolumn{4}{|c|}{ Gain for decreased age ate sexual maturity for -1 day $=36.50 \times(-1) / 15 \quad=-2.433 \mathrm{P}$} \\
\hline G1 (DN10) & Selected line & Item & Control line \\
\hline Feed cost & $\begin{array}{l}11.86 * 25 * 270 \mathrm{P} / \mathrm{Kg} \\
\text { diet }=80.12 \mathrm{P}\end{array}$ & Feed cost & $\begin{array}{l}13.95 * 25 * 270 \mathrm{P} / \mathrm{Kg} \\
\mathrm{diet}=94.16\end{array}$ \\
\hline $\begin{array}{l}\text { Other cost }(0.5 \text { total } \\
\text { feed cost })\end{array}$ & $40.06 \mathrm{P}$ & $\begin{array}{l}\text { Other cost }(0.5 \text { total } \\
\text { feed cost })\end{array}$ & $47.08 \mathrm{P}$ \\
\hline Total & $120.18 \mathrm{P}$ & Total & $141.24 \mathrm{P}$ \\
\hline $\begin{array}{l}\text { Income } 10 \text { egg x } 15 \mathrm{P} \\
\text { price for one egg }\end{array}$ & $150 \mathrm{P}$ & $\begin{array}{l}\text { Income } 10 \text { egg x } 15 \\
P \text { price for one egg }\end{array}$ & $150 \mathrm{P}$ \\
\hline Gain & $=150-120.18=29.82 \mathrm{P}$ & Gain & $=150-141.24=8.76 \mathrm{P}$ \\
\hline \multicolumn{4}{|c|}{ Gain for decreased $\mathrm{DN}_{10}$ for -0.5 day for $2 \mathrm{SD}=(29.82-8.76) \times(-0.5) / 8.2=-1.284 \mathrm{P}$} \\
\hline G1 (AGE10) & Selected line & Item & Control line \\
\hline Feed cost & $\begin{array}{l}60.19 \text { days } \mathrm{x} 25 \mathrm{~g} \mathrm{x} \\
270 \mathrm{P} / \mathrm{kg} \text { diet }=406.28\end{array}$ & Feed cost & $\begin{array}{l}65.70 \text { days } \times 25 \mathrm{~g} \mathrm{x} \\
270 \mathrm{P} / \mathrm{kg} \text { diet }=443.47\end{array}$ \\
\hline $\begin{array}{l}\text { Other cost }(0.5 \text { total } \\
\text { feed cost) }\end{array}$ & $203.14 \mathrm{P}$ & $\begin{array}{l}\text { Other cost ( } 0.5 \text { total } \\
\text { feed cost) }\end{array}$ & $221.735 \mathrm{P}$ \\
\hline Total & $609.42 \mathrm{P}$ & Total & $665.2 \mathrm{P}$ \\
\hline \multicolumn{4}{|c|}{ Income $=10$ egg x $15 \mathrm{P}$ price for one egg + Price of quail at sexual maturity $=750 \mathrm{P}$} \\
\hline Gain & $=750-609.42=140.58$ & Gain & $=750-665.2=84.8 \mathrm{P}$ \\
\hline
\end{tabular}

Table (2): Economic values (EV) and relative economic values (REV) of the studied generation.

\begin{tabular}{|l|l|l|l|l|l|l|}
\hline \multirow{2}{*}{ Gen. } & \multicolumn{2}{|c|}{ ASM } & \multicolumn{2}{c|}{ DN $_{\mathbf{1 0}}$} & \multicolumn{2}{c|}{ AGE $_{\mathbf{1 0}}$} \\
\cline { 2 - 7 } & \multicolumn{1}{|c|}{ EV } & \multicolumn{1}{c|}{ REV } & \multicolumn{1}{c|}{ EV } & \multicolumn{1}{c|}{ REV } & \multicolumn{1}{c|}{ RV } \\
\hline $\mathrm{G}_{1}$ & -2.433 & -1.00 & -1.28 & -0.526 & -1.519 & -0.624 \\
$\mathrm{G}_{2}$ & -4.219 & -1.73 & -1.72 & -0.706 & -1.999 & -0.821 \\
$\mathrm{G}_{3}$ & -2.42 & -0.99 & -2.586 & -1.06 & -2.58 & -1.068 \\
$\mathrm{G}_{4}$ & -9.74 & -4.00 & -0.719 & -0.295 & -4.30 & -1.767 \\
\hline
\end{tabular}


Table (3): Means and standard errors (SE) for generation and line effects on body weight at different ages.

\begin{tabular}{|l|l|l|l|l|l|l|}
\hline \multicolumn{1}{|c|}{ Effect } & \multicolumn{1}{c|}{$\mathbf{B W}_{\mathbf{1}}$} & \multicolumn{1}{c|}{$\mathbf{B W}_{\mathbf{7}}$} & \multicolumn{1}{c|}{$\mathbf{B W}_{\mathbf{1 4}}$} & \multicolumn{1}{c|}{$\mathbf{B W}_{\mathbf{2 1}}$} & \multicolumn{1}{c|}{$\mathbf{B W}_{\mathbf{2 8}}$} & \multicolumn{1}{c|}{$\mathbf{B W}_{\mathbf{3 5}}$} \\
\hline Generation & \\
1 & $8.73^{\mathrm{b}}$ & $27.34^{\mathrm{c}}$ & $60.67^{\mathrm{b}}$ & $103.07^{\mathrm{b}}$ & $143.08^{\mathrm{b}}$ & 186.40 \\
2 & $9.07^{\mathrm{a}}$ & $29.57^{\mathrm{b}}$ & $52.99^{\mathrm{c}}$ & $91.57^{\mathrm{c}}$ & $123.41^{\mathrm{c}}$ & 185.76 \\
3 & $9.12^{\mathrm{a}}$ & $31.44^{\mathrm{a}}$ & $65.75^{\mathrm{a}}$ & $104.94^{\mathrm{b}}$ & $151.76^{\mathrm{a}}$ & 192.12 \\
4 & $8.48^{\mathrm{c}}$ & $27.55^{\mathrm{c}}$ & $66.09^{\mathrm{a}}$ & $109.19^{\mathrm{a}}$ & $148.67^{\mathrm{a}}$ & 191.54 \\
$\mathrm{SE}$ & 0.096 & 0.529 & 0.975 & 1.554 & 2.135 & 2.264 \\
$\mathrm{P}$ value & $\mathrm{P} \leq 0.000$ & $\mathrm{P} \leq 0.000$ & $\mathrm{P} \leq 0.000$ & $\mathrm{P} \leq 0.000$ & $\mathrm{P} \leq 0.000$ & $\mathrm{P} \leq 0.241$ \\
Line & \\
Control & 8.87 & $26.76^{\mathrm{b}}$ & $56.37^{\mathrm{b}}$ & $92.73^{\mathrm{b}}$ & $128.16^{\mathrm{b}}$ & $175.09^{\mathrm{b}}$ \\
Selected & 8.86 & $31.08^{\mathrm{a}}$ & $65.61^{\mathrm{a}}$ & $111.69^{\mathrm{a}}$ & $153.63^{\mathrm{a}}$ & $202.01^{\mathrm{a}}$ \\
$\mathrm{SE}$ & 0.061 & 0.339 & 0.648 & 0.989 & 1.389 & 1.460 \\
$\mathrm{P}$ value & $\mathrm{P} \leq 0.922$ & $\mathrm{P} \leq 0.000$ & $\mathrm{P} \leq 0.000$ & $\mathrm{P} \leq 0.000$ & $\mathrm{P} \leq 0.000$ & $\mathrm{P} \leq 0.000$ \\
\hline
\end{tabular}
a,b and c $:$ Means having different superscripts within each generation and line effect in

the same column are significantly different at specified $\mathrm{P}$. 
Table (4): Means and standard errors (SE) for generation and line effects on

\begin{tabular}{|c|c|c|c|c|c|c|c|c|c|c|c|}
\hline Effect & \multicolumn{4}{|c|}{ Multi-trait index } & \multicolumn{7}{|c|}{ Egg production-related traits } \\
\hline 1 & $50.78^{b}$ & $12.91^{\mathrm{a}}$ & $237.94^{\mathrm{bc}}$ & $62.95^{\mathrm{b}}$ & $112.53^{c}$ & $349.25^{b}$ & $712.75^{\mathrm{b}}$ & $39.18^{\mathrm{a}}$ & $76.38^{\mathrm{a}}$ & 88.60 & $127.33^{\mathrm{a}}$ \\
\hline 2 & $52.49^{\mathrm{a}}$ & $12.12^{\mathrm{ab}}$ & $250.57^{\mathrm{a}}$ & $63.96^{\mathrm{a}}$ & $121.72^{\mathrm{a}}$ & $376.13^{\mathrm{a}}$ & $759.33^{\mathrm{a}}$ & $36.03^{b c}$ & $72.64^{b}$ & 87.76 & $124.90^{\mathrm{a}}$ \\
\hline 4 & $53.50^{\mathrm{a}}$ & $11.64^{\mathrm{b}}$ & $235.32^{\mathrm{c}}$ & $65.55^{\mathrm{a}}$ & $115.48^{b}$ & $344.25^{\mathrm{bc}}$ & $702.78^{\mathrm{bc}}$ & $35.22^{c}$ & $68.76^{\mathrm{c}}$ & 88.49 & $121.41^{\mathrm{b}}$ \\
\hline SE & 0.54 & 0.36 & 2.44 & 0.65 & 0.98 & 2.42 & 4.93 & 0.67 & 1.12 & 0.94 & 1.31 \\
\hline$P$ value & $\mathrm{P} \leq 0.000$ & $\mathrm{P} \leq 0.000$ & $\mathrm{P} \leq 0.000$ & $\mathrm{P} \leq 0.001$ & $\mathrm{P} \leq 0.000$ & $\mathrm{P} \leq 0.000$ & $\mathrm{P} \leq 0.000$ & $\mathrm{P} \leq 0.000$ & $\mathrm{P} \leq 0.000$ & $\mathrm{P} \leq 0.578$ & $P \leq 0.009$ \\
\hline Selected & $47.74^{\mathrm{b}}$ & $11.30^{\mathrm{b}}$ & $244.60^{\mathrm{a}}$ & $58.91^{\mathrm{b}}$ & $116.89^{a}$ & 353.82 & 721.20 & $34.21^{\mathrm{b}}$ & $69.10^{\mathrm{b}}$ & $81.76^{\mathrm{b}}$ & $116.43^{b}$ \\
\hline $\mathrm{SE}$ & 0.33 & 0.22 & 1.51 & 0.40 & 0.60 & 1.51 & 3.11 & 0.43 & 0.75 & 0.59 & 0.89 \\
\hline $\mathrm{P}$ value & $\mathrm{P} \leq 0.000$ & $\mathrm{P} \leq 0.000$ & $\mathrm{P} \leq 0.001$ & $\mathrm{P} \leq 0.000$ & $\mathrm{P} \leq 0.003$ & $\mathrm{P} \leq 0.436$ & $\mathrm{P} \leq 0.395$ & $\mathrm{P} \leq 0.000$ & $\mathrm{P} \leq 0.000$ & $\mathrm{P} \leq 0.000$ & $\mathrm{P} \leq 0.000$ \\
\hline
\end{tabular}
some related-egg production traits.

a,b and ${ }^{c}$ :Means having different superscripts within each generation and line effect in the same column are significantly different at specified $P$. 
Table (5): Means and standard errors (SE) for generation $x$ line body weight at different ages.

\begin{tabular}{|l|l|l|l|l|l|l|l|}
\hline Generation & \multicolumn{1}{|c|}{ Line } & \multicolumn{1}{|c|}{ BW1 } & \multicolumn{1}{|c|}{ BW7 } & \multicolumn{1}{|c|}{ BW14 } & \multicolumn{1}{|c|}{ BW21 } & \multicolumn{1}{c|}{ BW28 } & BW35 \\
\hline \multirow{2}{*}{1} & Control & $8.56^{\mathrm{c}}$ & $23.66^{\mathrm{e}}$ & $51.58^{\mathrm{e}}$ & $88.76^{\mathrm{d}}$ & $121.37^{\mathrm{d}}$ & $173.32^{\mathrm{d}}$ \\
& Selected & $8.86^{\mathrm{bc}}$ & $30.29^{\mathrm{b}}$ & $67.06^{\mathrm{ab}}$ & $115.19^{\mathrm{a}}$ & $160.05^{\mathrm{ab}}$ & $196.63^{\mathrm{b}}$ \\
\hline \multirow{2}{*}{2} & Control & $9.02^{\mathrm{b}}$ & $27.51^{\mathrm{cd}}$ & $49.30^{\mathrm{e}}$ & $80.95^{\mathrm{e}}$ & $113.92^{\mathrm{d}}$ & $170.89^{\mathrm{d}}$ \\
& Selected & $9.13^{\mathrm{b}}$ & $32.57^{\mathrm{a}}$ & $58.34^{\mathrm{d}}$ & $107.36^{\mathrm{b}}$ & $136.95^{\mathrm{c}}$ & $207.19^{\mathrm{a}}$ \\
\hline \multirow{2}{*}{3} & Control & $9.77^{\mathrm{a}}$ & $29.41^{\mathrm{bc}}$ & $63.93^{\mathrm{bc}}$ & $94.65^{\mathrm{c}}$ & $134.98^{\mathrm{c}}$ & $170.62^{\mathrm{d}}$ \\
& Selected & $8.66^{\mathrm{c}}$ & $32.96^{\mathrm{a}}$ & $67.13^{\mathrm{ab}}$ & $112.41^{\mathrm{ab}}$ & $162.95^{\mathrm{a}}$ & $207.45^{\mathrm{a}}$ \\
\hline \multirow{2}{*}{4} & Control & $8.14^{\mathrm{d}}$ & $26.44^{\mathrm{d}}$ & $60.86^{\mathrm{cd}}$ & $106.55^{\mathrm{b}}$ & $142.37^{\mathrm{c}}$ & $185.55^{\mathrm{c}}$ \\
& Selected & $8.81^{\mathrm{bc}}$ & $28.59^{\mathrm{bc}}$ & $69.82^{\mathrm{a}}$ & $111.80^{\mathrm{ab}}$ & $154.56^{\mathrm{b}}$ & $196.78^{\mathrm{b}}$ \\
\hline SE & & 0.144 & 0.788 & 1.454 & 2.307 & 3.199 & 3.393 \\
\hline P value & & $\mathrm{P} \leq 0.000$ & $\mathrm{P} \leq 0.000$ & $\mathrm{P} \leq 0.000$ & $\mathrm{P} \leq 0.000$ & $\mathrm{P} \leq 0.000$ & $\mathrm{P} \leq 0.000$ \\
\hline
\end{tabular}

$\mathrm{a}, b, \mathrm{c}$ and $\mathrm{d}$ :Means having different superscripts within the generation $\mathrm{x}$ line interaction in the same column are significantly different at specified $P$. 
Table (6): Means and standard errors (SE) for generation by line interaction on some egg production related traits.

\begin{tabular}{|c|c|c|c|c|c|c|c|c|c|c|c|c|}
\hline Generation & Line & ASM & $\mathbf{D N}_{10}$ & $\mathbf{B} \mathbf{W}_{\text {SM }}$ & $\mathbf{A} \mathbf{G} \mathbf{E}_{10}$ & $\mathbf{E} \mathbf{M}_{10}$ & $\mathbf{E M}_{30}$ & $\mathbf{E M}_{60}$ & $\mathbf{D N}_{30}$ & $\mathbf{D N}_{60}$ & $\mathbf{A G E} \mathbf{E}_{30}$ & $\mathbf{A G E}_{60}$ \\
\hline \multirow{2}{*}{1} & $\mathrm{C}$ & $52.72^{c}$ & $13.95^{\mathrm{b}}$ & 234.27 & $65.70^{b}$ & $112.81^{b}$ & $346.83^{b}$ & $702.63^{\mathrm{de}}$ & $41.46^{\mathrm{a}}$ & $78.19^{\mathrm{ab}}$ & $92.26^{b}$ & $131.23^{\mathrm{a}}$ \\
\hline & $S$ & $48.83^{\mathrm{d}}$ & $11.87^{\mathrm{cd}}$ & 241.60 & $60.19^{c}$ & $112.25^{\mathrm{bc}}$ & $351.67^{\mathrm{b}}$ & $722.87^{\mathrm{c}}$ & $36.89^{\mathrm{b}}$ & $74.56^{\mathrm{bc}}$ & $84.94^{c}$ & $123.44^{\mathrm{b}}$ \\
\hline \multirow[b]{2}{*}{2} & $\mathrm{C}$ & $55.00^{\mathrm{b}}$ & $13.09^{b c}$ & 246.52 & $67.98^{b}$ & $122.47^{\mathrm{a}}$ & $380.15^{\mathrm{a}}$ & $770.36^{\mathrm{a}}$ & $38.11^{\mathrm{b}}$ & $75.55^{\mathrm{abc}}$ & $92.79^{b}$ & $130.08^{\mathrm{a}}$ \\
\hline & S & $48.78^{\mathrm{d}}$ & $11.16^{\mathrm{d}}$ & 254.61 & $59.94^{\mathrm{cd}}$ & $120.98^{\mathrm{a}}$ & $372.10^{\mathrm{a}}$ & $748.30^{\mathrm{b}}$ & $33.94^{\mathrm{c}}$ & $69.72^{\mathrm{de}}$ & $82.73^{\mathrm{cd}}$ & $117.37^{\mathrm{c}}$ \\
\hline \multirow{2}{*}{3} & $\mathrm{C}$ & $52.08^{\mathrm{c}}$ & $15.28^{\mathrm{a}}$ & 235.90 & $67.28^{b}$ & $113.27^{b}$ & $347.69^{b}$ & $702.03^{\mathrm{de}}$ & $41.67^{\mathrm{a}}$ & $79.59^{\mathrm{a}}$ & $93.67^{b}$ & $131.78^{\mathrm{a}}$ \\
\hline & S & $46.49^{\mathrm{e}}$ & $11.09^{\mathrm{d}}$ & 246.30 & $57.91^{\mathrm{d}}$ & $112.36^{\mathrm{bc}}$ & $337.08^{\mathrm{c}}$ & $695.35^{\mathrm{e}}$ & $34.03^{c}$ & $67.65^{\mathrm{ef}}$ & $80.51^{\mathrm{de}}$ & $113.67^{\mathrm{cd}}$ \\
\hline \multirow{2}{*}{4} & $\mathrm{C}$ & $60.97^{\mathrm{a}}$ & $12.22^{\mathrm{cd}}$ & 235.00 & $73.19^{\mathrm{a}}$ & $109.05^{\mathrm{c}}$ & $334.62^{c}$ & $691.46^{\mathrm{e}}$ & $38.54^{b}$ & $73.13^{\mathrm{cd}}$ & $98.17^{\mathrm{a}}$ & $131.71^{\mathrm{a}}$ \\
\hline & $S$ & $46.54^{\mathrm{e}}$ & $11.06^{\mathrm{d}}$ & 235.64 & $57.58^{d}$ & $121.91^{\mathrm{a}}$ & $353.88^{\mathrm{b}}$ & $714.10^{\mathrm{cd}}$ & $31.91^{\mathrm{c}}$ & $64.39^{f}$ & $78.81^{\mathrm{e}}$ & $111.11^{\mathrm{d}}$ \\
\hline $\mathrm{SE}$ & & 0.78 & 0.52 & 3.35 & 0.94 & 1.43 & 3.56 & 7.36 & 0.98 & 1.70 & 1.35 & 2.09 \\
\hline $\mathrm{P}$ value & & $\mathrm{P} \leq 0.000$ & $\mathrm{P} \leq 0.002$ & $\mathrm{P} \leq 0.325$ & $\mathrm{P} \leq 0.000$ & $\mathrm{P} \leq 0.000$ & $\mathrm{P} \leq 0.000$ & $\mathrm{P} \leq 0.000$ & $\mathrm{P} \leq 0.016$ & $\mathrm{P} \leq 0.018$ & $\mathrm{P} \leq 0.000$ & $\mathrm{P} \leq 0.001$ \\
\hline
\end{tabular}

$\mathrm{C}$ : control line, $\mathrm{S}$ : selected line.

Table (7): Heritability (on diagonal), genetic (above the diagonal); phenotypic (below the diagonal) correlations ( \pm standard errors) for the multi-index traits studied. ${ }^{1}$

\begin{tabular}{|l|l|l|l|l|}
\hline & \multicolumn{1}{|c|}{ ASM } & \multicolumn{1}{|c|}{ BW $_{\text {SM }}$} & \multicolumn{1}{|c|}{ DN $_{\mathbf{1 0}}$} & \multicolumn{1}{c|}{ AGE $_{\mathbf{1 0}}$} \\
\hline $\mathrm{ASM}$ & $0.21 \pm 0.12$ & $0.50 \pm 0.10$ & $0.47 \pm 0.315$ & $0.95 \pm 0.03$ \\
$\mathrm{BW}_{\mathrm{SM}}$ & $0.17 \pm 0.04$ & $0.24 \pm 0.10$ & $0.57 \pm 0.41$ & $0.54 \pm 0.20$ \\
$\mathrm{DN}_{10}$ & $0.09 \pm 0.04$ & $-0.03 \pm 0.04$ & $0.09 \pm 0.06$ & $0.65+0.03$ \\
$\mathrm{AGE}_{10}$ & $0.86 \pm 0.01$ & $0.18 \pm 0.03$ & $0.23 \pm 0.03$ & $0.27 \pm 0.09$ \\
\hline
\end{tabular}

${ }^{\mathrm{A}} \mathrm{ASM}$ : age at first egg, $\mathrm{BW}_{\mathrm{SM}}$ : body weight at sexual maturity, $\mathrm{DN}_{10}$ : days needed to produce the first ten eggs and $\mathrm{AGE}_{10}$ : age at first 10 eggs. 
Table (8): Direct response to selection as average phenotypic, genetic responses per generation, expected, effective selection differentials, its ratio and realized heritability for the multi-index traits studied.

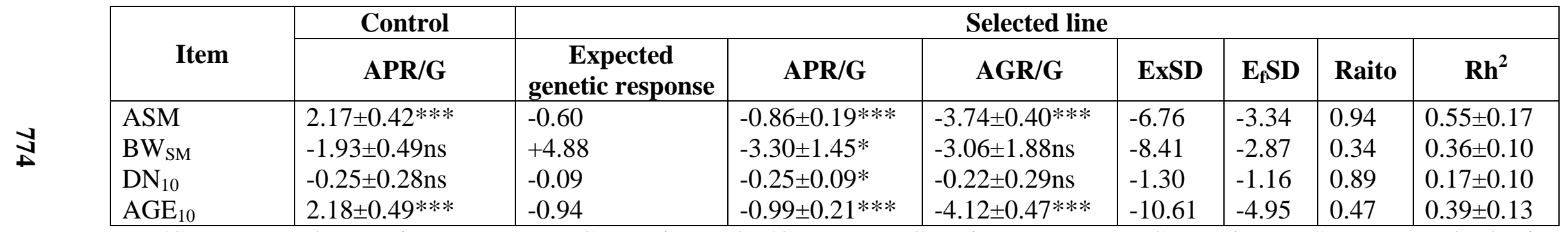

APR/G: Average Phenotypic Response per Generation, AGR/G: Average Genetic Response per Generation, ExSD :Expected selection differential,„E $\mathrm{E}_{\mathrm{f}} \mathrm{SD}$ : Effective selection differential and $\mathrm{Rh}^{2}$ : Realized heritability. 
Table (9): Response to selection for correlated traits: body weight, egg mass, days needed to produce eggs and ages of hens during studied periods of egg production.

\begin{tabular}{|c|c|c|c|}
\hline & $\begin{array}{c}\text { Average Phenotypic } \\
\text { Response per } \\
\text { Generation }\end{array}$ & $\begin{array}{c}\text { Average Phenotypic } \\
\text { Response per } \\
\text { Generation }\end{array}$ & $\begin{array}{c}\text { Average Genetic } \\
\text { Response per } \\
\text { Generation }\end{array}$ \\
\hline Line & Control line & \multicolumn{2}{|c|}{$\begin{array}{l}\text { Selected line } \\
\end{array}$} \\
\hline \multicolumn{4}{|c|}{ Correlated traits: } \\
\hline \multicolumn{4}{|c|}{ Body weight at different ages: } \\
\hline $\mathrm{BW}_{1}$ & $-0.11 \pm 0.07 \mathrm{~ns}$ & $-0.09 \pm 0.05 \mathrm{~ns}$ & $0.15 \pm 0.11 \mathrm{~ns}$ \\
\hline $\mathrm{BW}_{7}$ & $0.79 \pm 0.05 *$ & $-0.51 \pm 0.30 \mathrm{~ns}$ & $-0.68 \pm 0.46 n s$ \\
\hline $\mathrm{BW}_{14}$ & $4.55 \pm 0.69 * * *$ & $1.97 \pm 0.56^{* * *}$ & $-0.41 \pm 1.01 \mathrm{~ns}$ \\
\hline $\mathrm{BW}_{21}$ & $6.84 \pm 1.04 * * *$ & $-0.13 \pm 0.74 n s$ & $-3.97 \pm 1.42 * *$ \\
\hline $\mathrm{BW}_{28}$ & $7.58 \pm 1.42 * * *$ & $1.19 \pm 1.12 \mathrm{~ns}$ & $-1.99 \pm 1.01 \mathrm{~ns}$ \\
\hline $\mathrm{BW}_{35}$ & $4.36 \pm 1.58 * *$ & $-0.07 \pm 1.1 \mathrm{~ns}$ & $0.04 \pm 0.001 \mathrm{~ns}$ \\
\hline \multicolumn{4}{|c|}{ Egg production-related traits: } \\
\hline $\mathrm{EM}_{10}$ & $-3.10 \pm 0.64 * * *$ & $1.75 \pm 0.59 * *$ & $4.96 \pm 0.84 * * *$ \\
\hline $\mathrm{EM}_{30}$ & $-9.69 \pm 0.18 * * *$ & $-3.98 \pm 1.49 * *$ & $6.36 \pm 2.26 * *$ \\
\hline $\mathrm{EM}_{60}$ & $-15.96 \pm 3.54 * * *$ & $-8.55 \pm 2.92 * *$ & $2.68 \pm 5.00 \mathrm{~ns}$ \\
\hline $\mathrm{DN}_{30}$ & $-0.36 \pm 0.52 \mathrm{~ns}$ & $-1.41 \pm 0.24 * * *$ & $-1.00 \pm 0.55 \mathrm{~ns}$ \\
\hline $\mathrm{DN}_{60}$ & $-0.74 \pm 0.92 \mathrm{~ns}$ & $-3.26 \pm 0.45^{* * *}$ & $-2.16 \pm 0.98^{*}$ \\
\hline $\mathrm{AGE}_{30}$ & $1.96 \pm 0.72 * *$ & $-2.06 \pm 0.32 * * *$ & $-4.87 \pm 0.68 * * *$ \\
\hline $\mathrm{AGE}_{60}$ & $0.47 \pm 1.06 \mathrm{~ns}$ & $-4.07 \pm 0.52 * * *$ & $-4.92 \pm 1.04 * * *$ \\
\hline
\end{tabular}

$*$ :Significant at $\mathrm{P} \leq 0.05, * *$ : Significant at $\mathrm{P} \leq 0.01$, ***: Significant at $\mathrm{P} \leq 0.001$ and $\mathrm{ns}$ : Not significant.

\section{REFERENCES}

Aboul-Seoud (2008). Divergent Selection for Growth and Egg Production Traits in Japanese quail.Ph.D.Thesis, Fac. Agric., AlAzhar, University.

Ali, B. A., M. M. Ahmed, M. Bahie ElDeen and H. M. Shalan (2002). Genetic variability in the $17^{\text {th }}$ generation of Japanese quail selected for high eggs and meat production. Egypt. Poult. Sci., 22: 59-71.

Alkan, S., T. Karsli, K . Karaba $\breve{G}$ and A. Galiç (2013). The effects of selection and season on clutch traits and egg production in Japanese
Quails (Coturnixcoturnix Japonica) of different lines.Süleyman Demirel Üniversitesi Ziraat Fakültesi Dergisi 8, 71-77.

Amao, S. R. , L. O. Ojedapo, O. A. Sosina (2011). Evaluation of growth performance traits in three strains of broiler chickens reared in derived savanna environment of Nigeria. World J Young Researchers 2011; 1(2):28 -31.

Bahie El-Deen, M. (1994). Selection indices and crossing as a tool for improvement meat and egg production in Japanese quail. Ph.D. Thesis, Fac. Agric. Alexandria. Univ., Egypt. 
Bekele, F., T. Ådnøy, H.M. Gjøen, J. Kathle and Girma Abebe (2010). Production performance of dual purpose crosses of two indigenous withtwo exotic chicken breeds in sub-tropical environment. International J. Poult. Sci., 9 (7): 702-710.

Brah, G. S., M. Chaudhary and J. S. Sandhu (2001). Direct and correlated responses to selection for 4-week body weight in two lines of Japanese quails. Arch. Tierz., Dummerstorf 44, 99-108

Camci, O., C. Erensayin and S. Aktan, (2002). Relations

between age at sexual maturity and some production characteristic in quails. Archiv Geflugelk 66(6):280282.

Duncan,D.B. (1955). Multiple range and multiple F-tests. Biometrics11 (1):1-42.

Farrag, S. A. (2011). Genetic variation within and between quail lines selected for high body weight at four weeks of age and egg production using DNA fingerprinting. Ph.D. Thesis, Fac. Farm Technology and Food Safety. Kazakh National Agrarian, Univ. Kazakhstan.

Gunes, $H$ and $H$. Cerit (2001). Interrelation ships between age at sexual maturity, body weight and in the Japanese quail. Veteriner. Fakultesi-DergisiIstanbul, 27:1, 191-198.

Hill, W.G. (1972) Estimation of genetic change. 1. General theory and design of control populations. Anim. Breed. Abstr., 40, 1-5

Khaldari, M., A. Pakdel, H. Mehrabani Yegane, A. Nejati Javaremi and P. Berg (2010). Response to selection and genetic parameters of body and carcass weights in Japanese quail selected for 4-week body weight. Poult. Sci. 89:18341841.

Kolstad, N. (1975). Selesksjonsidekser for verpehons. Institute of poultry and fur Animal Sci., Agric. Univ of Norway, NLH, Stensiltryykk No. 72.

Martinez, V., L. Baunger, and W. G. Hill (2000). Analysis of response to 20 generations of selection for body composition in mice: Fit to infinitesimal model assumptions. Genet. Sel. Evol. 32:3-21.

Narendra Nath, D., F.R. Sheriff, R. Prabakaran and R. Asha Rajini (2011). Response to short -term index selection for economic traits in meat type Japanese quail. J. Indian Veterinary Science IVA, 9(3), 10-14.

Naser, M.A. and A.A. Abbas (2012). Genetic evaluation and estimation of genetic and phenotypic parameters of productive traits in quails. Iraqi. J. Poult. Sci. 6 (2):2238.

Nestor, K.E., W.L. Bacon and A.L. Lambio (1982).Divergent selection for body weight and yolk precursor in Coturnixcoturnix japonica.1. Selection response. Poult. Sci., 61: 12-17.

N R C (1994). Nutrient Requirements of Poultry,National Research Council,.9th Revised. Ed., National Academy of Sciences Press, Washington, D.C., USA.

Okenyi, N., H. M., Ndofor-Foleng, C. C. Ogbu and C. I. Agu (2013). Genetic parameters and consequences of selection for short-term egg production traits in Japanese quail in a tropical environment. African J. Biotechnology Vol. 12 (12), 13571362. 
Okuda, E.U., M. Orunmoyia, I.A. Adeyinkaa, E.D. Ezeb, A.J. Shoyomboa and U. Louisc (2014). Estimation of genetic parameters of egg production and reproductive traits in Japanese quails. Agricultural Advances 3 (1) 19-27.

Oruwari, B.M. and T. Brody (1988). Roles of age, body weight and composition in the initiation of sexual maturation of Japanese quail (Coturnix coturnix japonica). Br. Poult. Sci. 29(3):481-489.

Punya Kumari, B. (2007). Genetic studies on the performance of Japanese quails. Ph.D. thesis submitted to Sri Venkateswara Veterinary University, Tirupathi.

Raj Narayan, D.P. Singh, S.K. Agarwal and S. Majumdar (2000). Efficiency of selection indices for the improvement of economic traits in Japanese quail. Indian J. Poult. Sci, 35(1): 89-90.

Reddish, M. (2004). Evaluation of the effects of selection for increased body weight and increased yield on growth and development of poultry. $\mathrm{Ph}$. D. Thesis, Ohio State University.

Sakunthala Devi, K. and B. Ramesh Gupta (2012). Construction and evaluation of selection indices for improvement of body weights in brown strain of Japanese quail. International J. Pharm. Biology Sci. 3(4), (B) $429-437$
SAS (2011). SAS/STAT Users Guide: Statistics. Version 9.3, SAS Institute Inc., Cary, NC.

Sezer, M. (2007). Genetic parameters estimated for sexual maturity and weekly live weights 9 of Japanese quail (Coturnix coturnix japonica). Asian-Australian J. Anim. Sci. 10 20(1), 19-24.

Sezer, M., E. Berberoglu and Z. Ulutas (2006). Genetic association between sexual maturity and weekly liveweights in laying-type Japanese quail. South African J. Anim. Sci. 13 36(2), 142-148

Shalan, H. M. (1998). Independent culling levels selection and crossing for improving meat and egg production in Japanese quail. Ph.D. Thesis, Fac. Agric. Alexandria. Univ., Egypt.

Singh, R. P. and J. Kumar (1994). Biometrical methods in poultry breeding .Kalyani Publishers, First edition. New Delhi.

Tawefeuk, F.A. (2001). Studies in quails breeding using selection index for the improvement of growth and egg production in Japanese quail. Ph.D. Thesis, Fac. Agric. Tanta, Univ. Egypt.

Zelenka, D. J., J. A. Cherry, I. Nir and P. B. Siegel (1984). Body weight and composition of Japanese quail (Coturnix coturnix japonica) at sexual maturity. Growth 48:1628. 


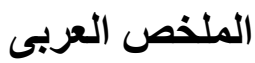

\section{الاستجابات المباشرة والمصاحبة لاليل الانتخاب قصير المدى لبعض الصفات الاقتصادية فى السمان اليابانى}

\author{
بثينة يوسف فؤاد محمود' ، جلال أبو خديجة' و إنصاف أحمد القل'

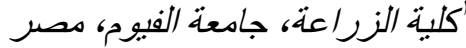

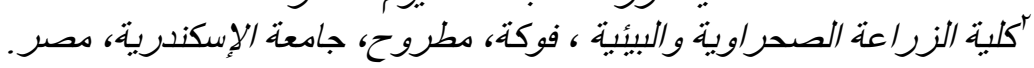

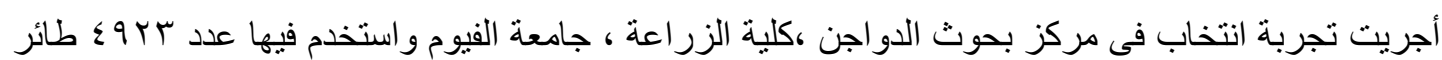

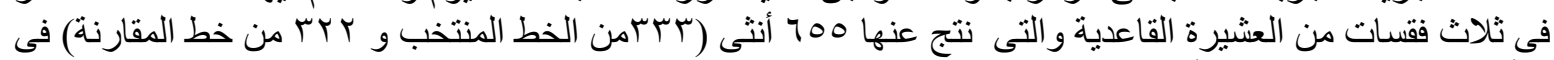

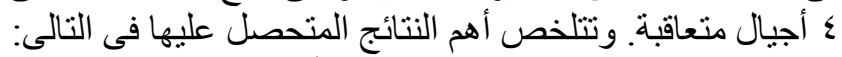

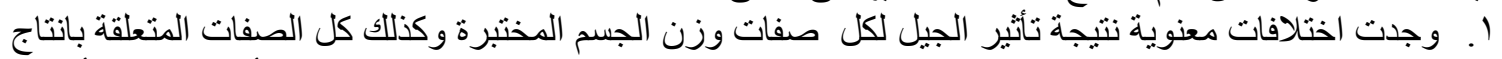

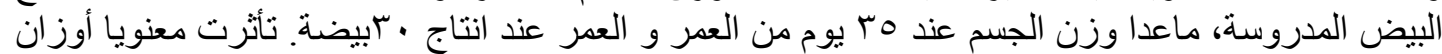

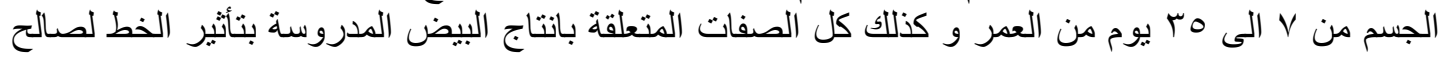

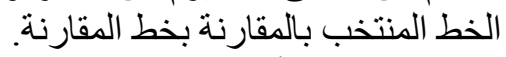

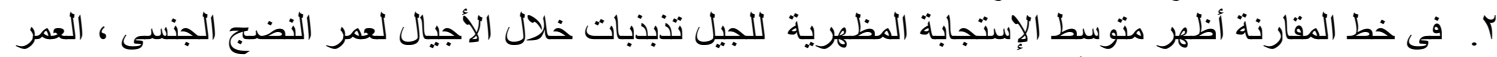

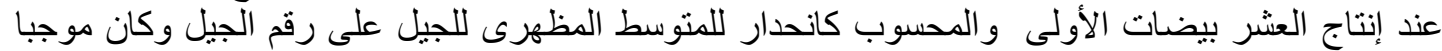

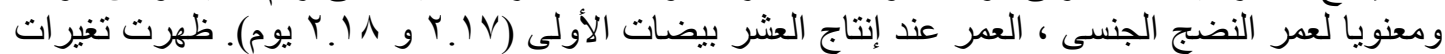

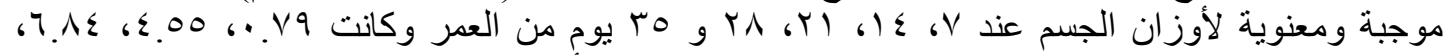

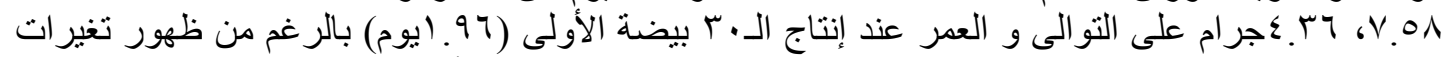

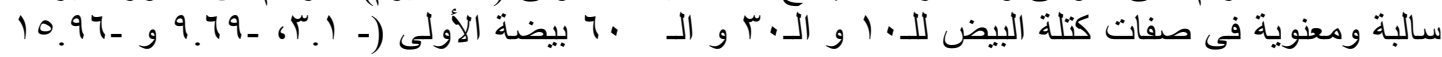

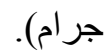

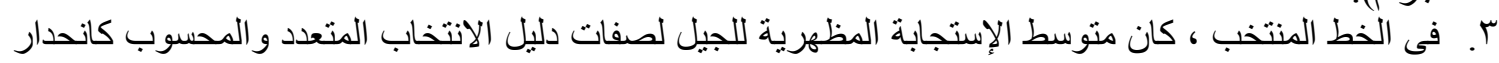

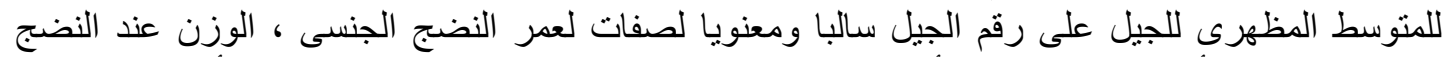

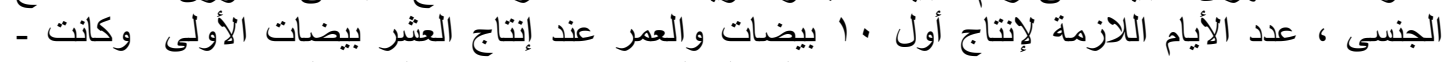

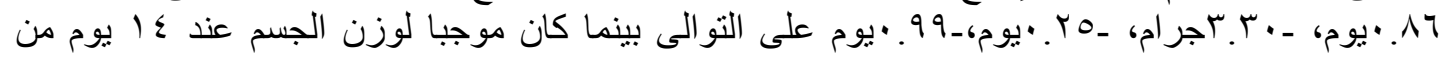

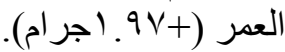

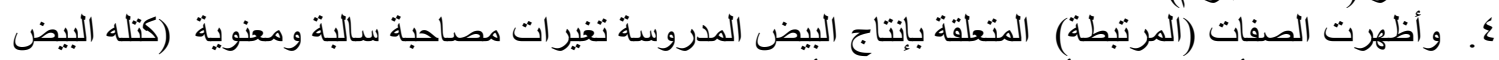

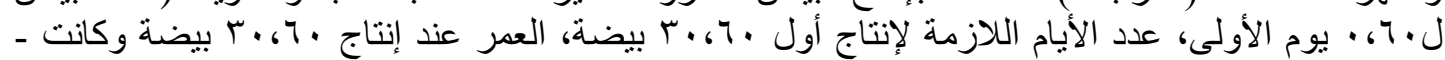

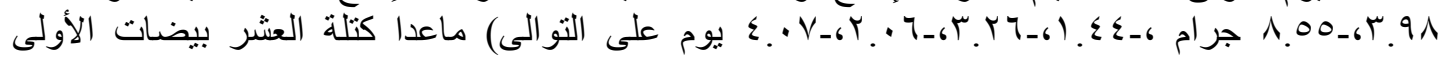

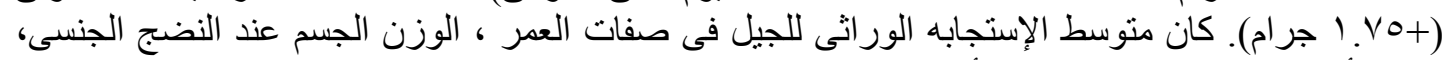

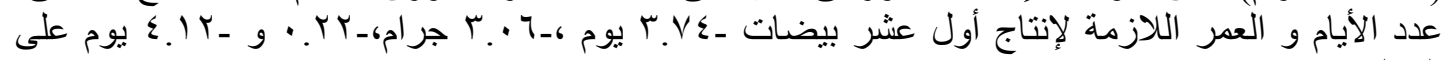

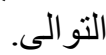

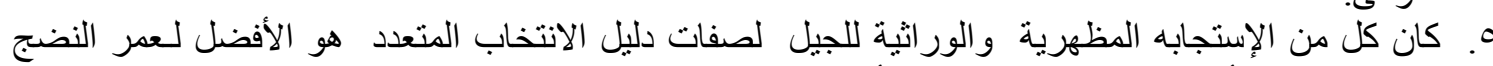

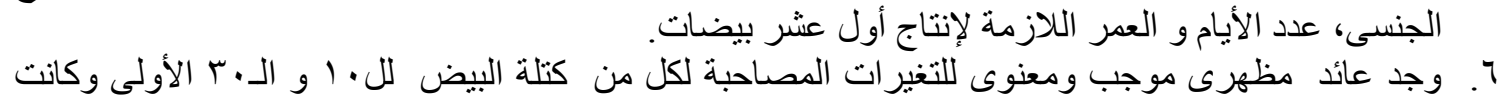

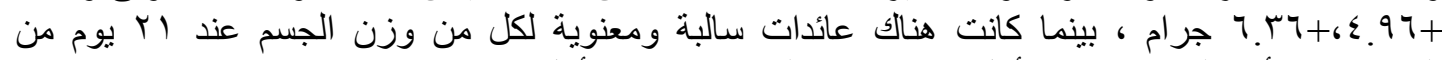

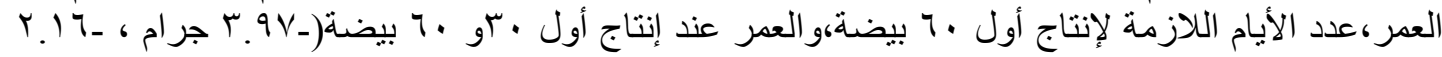

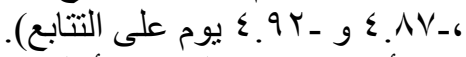

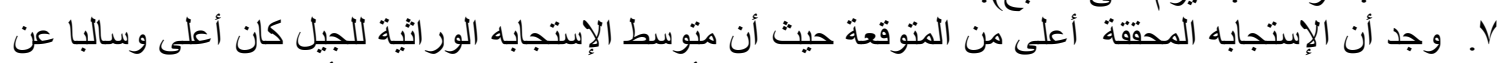

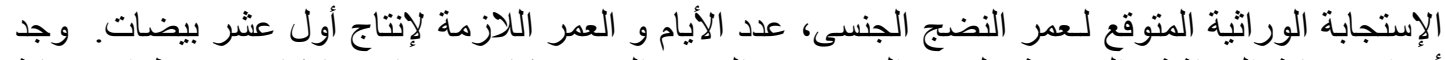

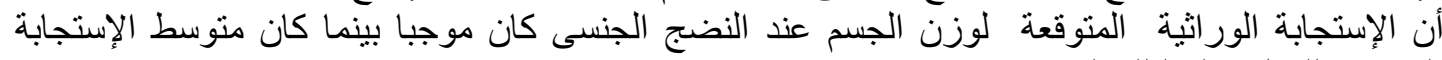

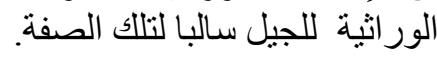

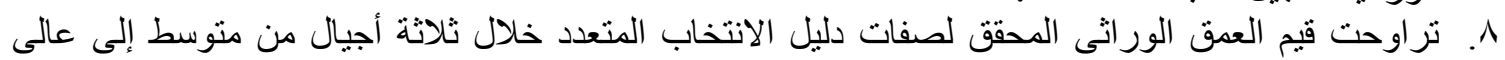

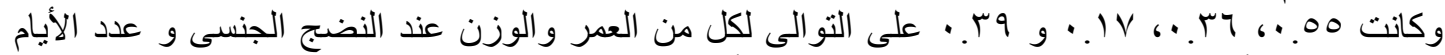

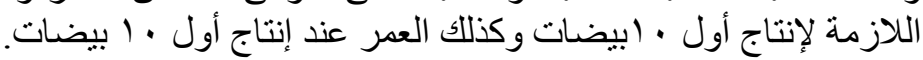

